\title{
6. THE NEW POLITICAL ECONOMY OF CORRUPTION
}

\author{
Mushtaq H. Khan \\ Department of Economics, SOAS.
}

(published in Fine, B., Lapavitsas, C., Pincus, J. (eds) Development Policy in the Twenty-First Century: Beyond the Post-Washington Consensus. London: Routledge 2001. pp. 112-35).

The shift in the interest of international agencies and of the World Bank, in particular in the 1990s towards issues of governance, is on the face of it long overdue. It appears that after a long hiatus, mainstream economists are returning to the political economy of growth in general and to the problems of policy implementation in particular. Evidently, the new consensus is to be welcomed as a huge improvement over the market theology of the 1980s. The state is now recognized as important, as are investments, and how effectively states and other non-state institutions, like financial institutions, work to create conditions conducive for investment must clearly have a lot to do with explaining growth and in directing policy attention when growth is poor. On the other hand, the new consensus is resistant to taking into account the role of political power in general, and in particular in explaining the patterns of corruption in different countries and the effects of this corruption. This is not because the importance of political corruption is not recognized. Economic theorists working on corruption as well as the Bank and IMF, have explicitly recognized the importance of political corruption. Rather, the problem is that political corruption is difficult to model and the policy implications of identifying this problem is that politics has to be targeted, a prospect that is not attractive to international institutions unless the political reform can be presented in terms familiar to their Western funding constituency.

This is why when the political underpinning of corruption has been discussed, the policy suggestions have been things like greater democratization or the encouragement of civil society participation in monitoring the state. Typically, economists and international agencies have shied away from trying to identify the classes and groups involved in corruption in different contexts, the consequences of their corruption in each case and the possible ways in which the political structure can be changed to change the magnitude or effects of corruption. We will argue that although economic models have made a contribution to our understanding of corruption, by leaving out the political determinants of corruption, these models are not just deficient but in many cases may be misleading. The required direction of reform may often be quite different from that suggested by the emerging models on corruption.

This chapter is structured in the following way. In the first section we discuss definitions of corruption and some of the evidence which has underpinned the recent interest in the phenomenon. In the next section we examine a number of contemporary approaches to corruption, focusing on the Shleifer-Vishny (1993) model of the effects of corruption under different institutional arrangements, as an example of the direction of research based on game theory models. Finally, in the last section we look at the importance of class and group structure in determining incentives for different types of corruption, which we argue are important for understanding corruption properly and responding to it in ways that have a 
chance of working. This section provides a critique of the new economics of corruption, which typically ignores the effects of class and group structure.

\section{Definitions, Types and the Evidence of Corruption}

Corruption is most usually defined as a violation of the formal rules governing the allocation of public resources by officials in response to offers of financial gain or political support. This definition is the one we will follow. This makes corruption narrower than theft, which refers to illegal transfers of both public and private property though in practise the distinction is difficult to apply because the frontier between public and private is not always clear. Corruption can also refer to a vast range of different types of phenomena and it may sometimes be quite misleading to use similar analytical tools to examine the implications of each. At the very least we can distinguish between two different motivations for corrupt acts: motivations that are primarily economic and those that are primarily political. Economic corruption refers to cases where a public official has the opportunity to allocate a valuable resource or make a decision that affects the economic gains or losses of others, and can bargain for a payoff to make a decision of a particular type. The bulk of the analysis of corruption undertaken by economists is about corruption of this type. However, corruption can be and often is politically motivated. Here the allocation of resources by the public officials, which includes politicians in power, is in response to the political payoffs that different constituencies can offer to the official and not just the economic payoff. The possibility of political corruption makes the analysis of corruption very difficult from the standpoint of pure economics since political and economic motivations are often combined in the same transaction.

Economic corruption appears to be endemic in developing countries and indeed there are systematic reasons why this should be the case. First, accumulation and the allocation of public resources in developing countries very frequently involves changes in established property rights and institutions, or the creation of entirely new ones. For these processes not to involve corruption in the formal sense defined above, the changes in rights and institutions or the allocation and creation of new rights would have to follow legally established rules. These rules would in general be very difficult to set up explicitly given the post-colonial political settlement in most developing countries, since in most cases explicit legal rules that aim to set up capitalist classes would very likely not enjoy widespread legitimacy. Thus, there may very frequently be substantial difficulties in following this route even if developing country leaders had wanted to be explicit about the types of changes in property rights that they wanted to bring about.

If a legal framework allowing primitive allocation cannot be formally constructed, any allocation of rights by the state that amounted to primitive accumulation would, by definition, be illegal because it would be disallowed by a legal framework copied from countries with more advanced property rights. Thus, when subsidies or land or the permission to import capital goods is being granted by the state to accelerate the creation of a new capitalist class, these allocations are often, strictly speaking, illegal because they cannot follow the procedural rules that have been set up to administer them. 
A second reason for widespread corruption in developing countries is that their states have typically played a much more important role in the economy. The role of the state has not only been large in the typical sluggish developing country, but, as has been recently recognized by many orthodox economists and the World Bank as well, the role of the state has also been extensive in the very successful industrializers in East Asia. Apart from primitive accumulation proper, rapid development can be achieved if rights can be reallocated in the form of subsidies and assistance to infant industries or for learning of new technologies, provided these subsidies are well managed and are withdrawn when their usefulness has expired. However, whether or not the subsidies are well-managed, there are never enough subsidies to accommodate all those who may legitimately benefit from them. The excess demand for subsidies in various forms to emerging industrialists or rich peasants also opens up possibilities of corruption since scarce resources had to be allocated bureaucratically.

Finally, there are good reasons why political corruption should also be widespread. Development inevitably involves the creation and entrenchment of a new class of property owners who often did not exist a generation ago. These early beneficiaries of development are clearly the winners of a game of property right allocation that will have consequences for generations to come. In many cases, the individuals who succeed in establishing their property rights and benefiting from subsidies at this critical stage only do so as a result of a great deal of good fortune, being at the right place at the right time or possessing the characteristics on which the rationing is carried out (such as language or sect). Given the inherent unfairness involved in these processes, it has been relatively easy to organise opposition to the state in most developing countries.

Opposition of this sort has typically been organised by members of emerging middle classes who have been left behind in the development process. It is therefore more intense in societies where these groups are better organised and entrenched. Their opposition has often resulted in a set of political pressures that have paradoxically generated even higher levels of corruption, this time through the route of political corruption. The opposition of organised groups to the development strategies of the state has typically been bought off by payoffs from existing elites or from the state to purchase a minimum level of support or legitimacy. These transfers have had to be surreptitiously organised because (in most cases) payoffs to opponents in proportion to their ability to make trouble could not, by their very nature, be publicly recorded in the budget. Many of these flows are interlocked with economic corruption and are difficult to separate by superficial observation. We will see later how the patterns of interlocking can have significant implications for the economic effects of corruption.

There is a final and more incidental reason why corruption is more widespread in developing countries. In an important sense, the problem of corruption is really about a much more essential problem in capitalist societies, which is the conflict between the logic of capitalism and the logic of liberal democratic legal systems and norms. The former tells us that the ability of individuals to influence the political decision-making process is proportional to the economic power of the individual. The latter tells us that political voice should be equalised as it is formally represented in the ideal of 'one-person one-vote'. The ways in which the 
economically powerful buy influence can be more generally described as rent-seeking, but most of the rent-seeking in advanced countries is legal. We have already discussed why much of the influence buying that goes on in developing countries cannot be legalised given the low legitimacy of the emerging capitalists.

This is the general background against which we need to examine the evolution of patterns of corruption in developing countries. The approach in this chapter will be to locate the processes of corruption in the context of the very different routes through which classes and property rights have been evolving in developing countries. We argue that, by so doing, we are better able to account for the differences in the apparent effects of corruption across countries. The processes of accumulation have been quite different across Asia. The rights that were being created for emerging capitalist classes and the terms under which these rights were being created differed greatly. Since the social utility of property rights depends quite a lot on which rights are created and the terms of their creation it is not surprising that the processes of corruption in these countries were associated with a very wide range of economic performance. To say this is not to justify corruption even under those conditions where it is associated with rapid growth. Rather, it is to point out that corruption can have much more damaging effects in contexts where it is associated with growth-retarding patterns of accumulation.

Does corruption have any effect on economic performance? Even if there is a negative relationship between corruption and economic performance, what does that mean? Is corruption an independent variable that can be altered to improve performance? Or is it an indication of problems that need to be directly tackled? Table 6.1, which looks at a small subset of Asian countries, throws some doubt on the type of regression analysis relating corruption to poor economic performance, of the type popularised by Paulo Mauro (1995) and others. We will look at these countries at greater length later. However, the table confirms that when we look at successful developers, it is difficult to find examples of development without corruption. This does not of course mean that corruption contributed to development, but it does mean that we have to be careful in drawing conclusions about the effects of corruption from large cross-section regressions. Even if the successful countries were not as corrupt as, say, Nigeria, the difference in the scale of their corruption is unlikely to explain any significant part of their difference in economic performance. In this sense the theories that look at the differences in the types of corruption are more likely to be useful, though we will have to look at both.

The relative magnitude of corruption is difficult to assess although it appears from journalistic, political and legal evidence that corruption was widespread in all these countries. The subjective evidence on corruption certainly suggests that the countries were quite similar in the key period of the 1970s and 1980s, when India and the South Asian countries had relatively low rates of growth compared to the East Asian countries. The Business International index for corruption in 1980-83 (on a scale from 0 for maximum corruption to 10 for no corruption) was 5.25 for India, 5.7 for South Korea and 6 for Malaysia (Mauro 1995). Given the crudity of these subjective indices these differences are not very significant. Thailand, on the other hand, had a very high corruption index of 1.5 for this 
period, suggesting a combination of large and widespread bribes faced by prospective businessmen.

Table 6.1 Corruption and economic performance

\begin{tabular}{cccc}
\hline Country & Corruption Index & \multicolumn{2}{c}{ GDP Growth Rates } \\
\hline & $1980-3$ & $1970-80$ & $1980-92$ \\
Malaysia & 6.0 & 7.9 & 5.9 \\
South Korea & 5.7 & 9.6 & 9.4 \\
India & 5.25 & 3.4 & 5.2 \\
Pakistan & 4.0 & 4.9 & 6.1 \\
Bangladesh & 4.0 & 2.3 & 4.2 \\
Thailand & 1.5 & 7.1 & 8.2 \\
\hline
\end{tabular}

Source: Mauro 1995; World Development Report 1994.

Note: A corruption index of 10 indicates 'no corruption', and an index of 0 indicates 'maximum corruption'.

By the mid-1990s, the subjective perception of corruption had increased in most of these countries. The only exception was Thailand, which was perceived to be the most corrupt country in the group in the 1980s, but by the 1990s was perceived to be less corrupt than the South Asian countries. What is interesting of course is that the most significant increase in corruption in the 1990s was in the South Asian countries, which paradoxically suffered less severely from the financial crisis of 1997. To the extent that the corruption index is trustworthy, it corroborates other evidence which suggests that the 1997 financial crisis raises some special issues which should not be confused with our long-run assessment of the implications of corruption in these countries. Clearly, we need to have an analytical framework that allows corruption to have differential effects in different countries. If corruption indeed has a uniform effect (whether good or bad) everywhere, this should be the conclusion reached the end of a process of evaluation and analysis rather than a presumption made at the outset. If, on the other hand, corruption can have variable effects, identifying these differences could be of great policy importance.

\section{New Approaches to Corruption}

Corruption is typically the exchange of a bribe for something in return, which is usually some allocation of economic rights. If we are concerned with the types of corruption, we should look at the specific economic rights that are exchanged. The real difference between countries may be that corruption is associated with value-enhancing rights being created in some cases and value-reducing rights in others. However, this is not the approach that is followed in the conventional approach to corruption, where the main target of analysis is the magnitude of corruption. This is because it is wrongly assumed that intervention is always value-reducing, so we can simply concentrate on differences in the magnitude of corruption to explain differences in performance across countries.

This perspective has produced the most widely held of the conventional economic arguments about what causes corruption and how to deal with it. An example is the World Development Report 1997, which identifies the 'causes' of corruption in line with this reasoning. Countries that have higher corruption have: 
1) a higher "policy distortion index" (for which read divergence from a notional free market);

2) a lower opportunity cost of being caught in the act of corruption (in the form of lower civil service to manufacturing salary ratios);

3) a less meritocratic bureaucracy (more political appointments and fewer exam-based appointments);

4) a lower predictability of the judicial system (measured by a lower probability of getting caught and being brought to justice).

Much of this is unexceptionable but is misleading. These correlations are then combined with the Mauro-type regressions where corruption is the independent variable. The policy conclusion is that if these primary causes (such as market distortion and civil service salaries) are addressed, the implication is that growth will improve. However, if corruption has more systemic causes, this argument may well be fallacious and, in the case of some types of liberalisation, the effects may even be damaging.

Broad overviews of the corruption literature already exist (see Bardhan 1997). In the remainder of this section, we will instead look at one important model of corruption in depth, which typifies the main problems faced by purely economic models in providing policyrelevant advice for tackling corruption. This is the Shleifer and Vishny (1993) model, which identifies the importance of the institutional structure of the state in determining the magnitude of corruption and therefore its economic effects. The basic result here is that centralized states are likely to engage in lower levels of corruption than more fragmented states, and in a second best world may be better.

The model like most others assumes that the competitive free-market outcome provides the benchmark of efficiency. The state sells monopoly rights (say to import) that restrict net social product. The more of these rights they sell and the lower the price (bribe), the better it is because output increases closer to the competitive level. If state agencies sell complementary rights (for instance, the right to import petrol may depend on how many rights have been sold to import cars), a centrally co-ordinated state will charge lower bribes for each right and be able to collect a higher total bribe because the level of activity will be higher. The logic behind this is that a centralised state acts as a monopsonist and is able to pick the profit-maximizing level of bribe for each sector. In contrast, a fragmented state, which has a number of independently acting agencies, will have each agency trying to maximize its profits. This leads to a prisoner's dilemma problem where each agency charges too high a bribe for its licenses, and as a result the overall level of activity drops and the total bribe collected also falls. Interestingly, the best outcome in this model is the case where the state is so fragmented that the level of bribes falls to zero because many different agencies are offering each right or license, and the price of each right offered by the state is bid down to zero!

The last point is highly misleading. A state approaching anything like that degree of fragmentation would not achieve efficiency, but rather it would descend into chaos as it would be unable to protect any rights at all. The more interesting comparison is between fully centralized and partly fragmented states. Superficially, this seems to explain why South Korea, say, had less damaging forms of corruption than, say, countries in the Indian 
subcontinent. However, on closer inspection, the model has a number of serious problems. First, the authors assume that state agencies are able to enforce their decisions. In fact, a particular problem in developing countries is that states, even when centralised, cannot implement the decisions they would like to. This has important implications because it means that states with formally centralised institutional structures can behave in a fragmented way if, for instance, powerful groups can prevent particular agencies from creating valueenhancing rights that hurt them. Thus, institutional centralization is not sufficient for coordination. The Indian state, for example, is formally as centralized as the Malaysian state but behaves very differently.

On the other hand, states whose formal institutional structures appear to be fragmented can sometimes behave in a coordinated way, particularly in repeated games - which games played by the state always are. Shleifer and Vishny's analysis is of a one-shot game, which is particularly inappropriate for modelling the state-society interaction even in terms of game theory. Rational strategies in an indefinitely repeated prisoner's dilemma game are indeterminate. Agencies in an institutionally fragmented state could act in a coordinated way in a repeated game provided the payoffs from coordination are large compared to the payoffs from non-coordination, and provided the time discount of officials is sufficiently low to make the future gains from repeated coordination worthwhile. Thus, institutional centralization may not even be necessary for coordination to emerge in repeated games. Even in South Korea, the formal centralization of the state was actually not absolute. There were different agencies such as the Economic Planning Board, the Ministry of Finance and the President who were making decisions, but in the repeated game their decisions were effectively coordinated. What allowed this to happen? Looking only at the agency structure is the starting point; it cannot be the whole story. We also have to look at the distribution of power that allowed one agency to co-ordinate the others and then to implement decisions.

Of course, another major problem with the Shleifer and Vishny model is that it assumes that states only create value-reducing licenses instead of often creating value-enhancing restrictions, property rights, taxes and subsidies, each of which could also be the subject of corruption. In this case the analysis of centralisation becomes more complex (Aoki et al. 1997, p. 6; Qian \& Weingast 1997; Khan 2000b). However, the problem we want to focus on now is that they do not model the significance of the distribution of power in determining how institutions actually behave.

\section{Class and Group Structure and the Implications for Corruption}

In contrast to the conventional approaches, which start with a bargaining problem between officials and citizens under different payoffs and institutional structures, we suggest that the bargaining story should be constructed after we have a picture of the bargaining power of the classes and groups participating in the bargain. There is a role for using some of the tools of modern game theory but they are only interesting once the bargaining context has been defined. One problem with identifying bargaining power at a high level of abstraction is that this is bound to raise many questions when we look at the evidence in detail for particular regions. Nevertheless, it is important to identify the most important features of a number of patterns even if we are forced to ignore aspects of detail that may be important for more narrowly defined problems. 
The most tractable way of fixing differences in class and group organization is to look at differences in patterns of redistributive flows in our sample countries on the basis of the literature on regional economic history and politics. Redistributive flows are flows of resources, both legal and illegal, which are a useful starting point for searching for the political and organizational differences between countries that can explain these flows. These political and organizational differences in turn serve as the starting point for a constructing a more complete analysis of why corruption is associated with different outcomes across countries. In this section we will identify a number of patterns in the distribution of power and indicate how they are relevant for explaining the association of similar amounts of corruption with very different outcomes in different countries. Before we proceed, we should say that political and organizational power changes over time, and the comparative story we are sketching is for the 1960s, 1970s and early 1980s when the East Asian countries were performing much better than the South Asian ones.

\section{South Asia}

Despite important differences between India, Pakistan and Bangladesh there are substantial similarities in the predominant types of redistributive flows in these countries. The most important similarity is in the complexity of the networks of interlinked redistributive flows. In all these countries a great number of groups compete for redistributive rents and in all of them members of the 'intermediate' or 'middle' classes play a key organizational and leadership role within these groups. These intermediate classes include in the main the educated sections of the population, both employed and unemployed and the richer peasants whose sons and daughters provide the new entrants into the educated classes through the universities and colleges and who themselves control opinion and electoral politics in the villages. Professionals (or white-collar workers) are a subset of the intermediate classes who have more privileged positions in the job market; political economists looking at India have frequently granted professionals a particularly important status. Bardhan (1984), for instance, identifies professionals as one of the three classes forming the coalition of dominant classes in India, together with capitalists and landlords. While we do not dispute the special position of professionals, we identify a wider and more loosely defined intermediate class, which includes college graduates and richer peasants, as the reservoir of organizational power from which leadership is provided for groups competing for redistributive rents.

The roots of the pivotal role played by the organizationally powerful intermediate classes go back at least to British colonial times, if not earlier. The tiny number of British in India could only have ruled with the complicity of indigenous Indian classes and groups, which potentially had the power to contest the colonial power. These groups included in the first instance landed elites and later members of the emerging 'middle class' both of which later became key components of anti-colonial party machines. The colonial state responded by creating divisions between classes and groups to create a finely balanced social edifice. The object of this exercise was to ensure that claims and counterclaims were finely balanced so that the state had to deal with only a small number of malcontents at any one time. On the other hand, because redistributions were based on organizational power, there were big gains for groups that could organize cross-class alliances more effectively. This is the reason 
for the proliferation of linguistic, religious and caste organizations. The lion's share of the benefits were of course captured by key 'middle class' professional organizers, but they could only succeed if they could mobilize large numbers of people around politically motivating symbols.

The political power of the intermediate groups is reflected in a state tradition of selective accommodation and incorporation of groups led by members of these classes. Subsequent institutional and political developments further strengthened these groups. Most political scientists agree that factional politics led by the intermediate classes intensified in India after the mid-1960s (see, for instance, Rudolph \& Rudolph 1987). A similar intensification is observed in Pakistan and later Bangladesh (Khan 2000b). The inherited tradition of mobilising support using a variety of emotive symbols was increasingly used by competing organizers to mobilize new groups of workers, peasants and the unemployed. These symbols included western ideological symbols as well as symbols derived from local languages, castes and religions. This pattern of politics has not enriched the vast majority of the populations of these countries but has enabled successive layers of emerging middle class groups to get access to rents on the basis of their ability to organise the much more numerous groups below them. Their access to rents is the result of the method of incorporation used by the state and by political leaders, which is to transfer redistributive rents to these groups. Some of these are perfectly legal (such as subsidies), while others are illegal transfers of resources or the transfer of illegally generated resources.

What is important is that a large part of the transfer (whether legal or illegal) through the state to intermediate classes of clients has been based on their political bargaining power. The more vociferous and well-organized a group, the greater the likelihood of accommodation, since resource constraints mean that not all groups could be accommodated all the time. Transfers in turn have had to be financed and state leaders have had to find resources either in general taxation or through rent-sharing arrangements with emerging capitalists who had access to other types of rents. The latter involved state leaders extracting a share of rents from elsewhere in the economy to meet the excess demand for transfers. An example would be local or state party organizations extracting rents from capitalists in the form of bribes and taxes to run local party machines which accommodated important local factions.

In addition, groups that could not be accommodated through the state were often directly incorporated by capitalists whose rents were threatened, since these factions could provide additional political muscle to defend the rents of the capitalist at a price. An example would be political factions offering to help particular capitalist or other rent-receiving interests in their conflicts with the state or against other groups in exchange for a share of the rents. These processes help to explain the dense structure of interlinked economic and political exchanges that Wade identified as characteristic of Indian corruption but did not adequately explain (Wade 1985, 1989, 1992). This type of interlinked rent-flows can be explained in terms of a growing set of demands for political redistribution, which in turn leads to an interlocking of rent extraction and distribution. 


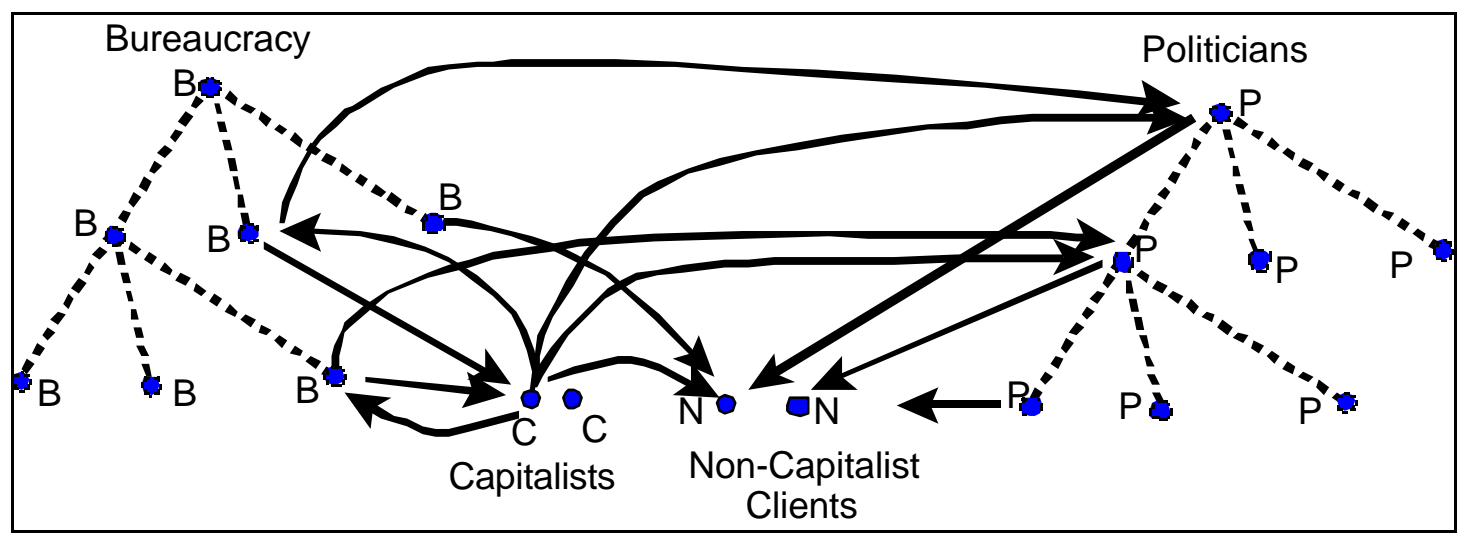

Figure 6.1 Rent flows in the Indian subcontinent: 1960s onwards

Figure 6.1 shows in a simple way the potential complexity of the flows of resources between the state, capitalists and political organizers in the typical South Asian political context. Bureaucrats (B) and politicians (P) constitute two parallel hierarchies within the state. For simplicity Figure 6.1 distinguishes between only two social groups, capitalists (C) and noncapitalists $(\mathrm{N})$, the latter being led in the main by the intermediate classes discussed earlier. The most successful non-capitalist organizers can often become political leaders or even capitalists over time. The most distinctive feature of the redistributive rent-flows in the Indian subcontinent is the transfers going from politicians at different levels to groups of noncapitalist clients (the arrows from $\mathrm{P}$ to $\mathrm{N}$ ). The quid pro quo from these clients to the state is not shown in Figure 6.1 because it is typically not an economic payoff but rather a 'payoff' in the form of political quiescence or support.

Like capitalists in many other developing countries, Indian capitalists have shared some of their rents directly with politicians and bureaucrats (the arrows from $\mathrm{C}$ to $\mathrm{P}$ and $\mathrm{B}$ ) in the form of taxes or bribes. These kickbacks from industrialists have in turn been an important source of finance for the political survival strategies of subcontinental politicians. In exchange, capitalists have received allocations of new property rights, which have often amounted to primitive accumulation as well as subsidies for learning to induce industrialisation or agricultural growth (shown collectively by the arrows from B to C). Finally, there are the rent flows going from capitalists to political groups (the arrows from $\mathrm{C}$ to $\mathrm{N}$ ) as capitalists buy 'protection'. We have argued that these flows in particular locked in local political power to particular rents, making structural change very slow in the Indian subcontinent compared to more rapidly developing countries.

While the networks of corruption and political payoffs in India have often been commented on, the economic implications of hese complex networks is usually underestimated. An important consequence of the fact that not all demands for redistribution could be met was the construction of a dense and shifting network of localised rent-sharing between rentrecipients of all types and political organizers, both within the state and outside it. This was to have severe consequences for the efficiency and growth associated with state intervention and in particular of the subsidies given to infant industries that the Indian state was engaged in managing. Once the interlocked networks had developed, allocations of subsidies proved very difficult to change since they were invariably protected by powerful local interests. The eventual result was the emergence of persistent subsidies for poorly performing industries 
and sectors, which were difficult to change in response to performance failures or changes in technologies and markets.

The pattern of redistributive rent-flows in India can provide at least part of an explanation for the persistence of inefficient learning subsidies, which effectively became monopoly rents for many industrialists. Thus, the observed corruption in India was associated with the maintenance and protection of inefficient and growth-reducing monopoly rents locked in with redistributive rents. The experiment with liberalization in the Indian subcontinent in the 1980s and 1990s has to be seen in this context. By reducing the amount of subsidy they were delivering, the states in these countries hoped to reduce redistributive politics and eventually the blocking effect coalitions played in processes of structural change. The likely outcome of this strategy is still in the balance. There is no evidence yet that redistributive politics have been effectively curtailed. Much of the early success of liberalization has been due to a boom in demand for consumer durables rather than to a decline in redistributive politics. It is only if the latter is achieved that liberalization would change the pattern of rentseeking in India in the long run (Harriss-White 1996, Khan 1996a). The limited evidence on corruption suggests that it may actually have increased, driven by more intense distributive conflicts.

\section{South Korea}

In contrast to the large and unstable redistributive transfers in South Asia, South Korea during the 1960s and 1970s was at the other end of the spectrum in terms of the magnitude and stability of politically driven redistributive rents. The pattern of resource flows appears to have been both different and simpler. This seems to have been particularly the case in the early days of industrial policy in the 1960s when commentators emphasized the degree of autonomy which the South Korean state enjoyed from competing demands in society (see, for instance, Jones \& Sakong 1980; Mason et al. 1980; Amsden 1989; Kim 1994, pp. 59-70; Kong 1996; Kim \& Ma 1997; Khan 2000a). The broad features of the South Korean case suggest a much higher degree of concentration of political power, which allowed the political executive to extract rents from beneficiaries of new rights without having to make political side-payments to non-capitalist clients to anything like the extent observed in South Asia. Thus although there is some redistributive rent-distribution going on throughout the 1960s and 1970s, particularly to the agricultural sector, this is not based on the political or organizational power of agrarian factions to demand redistributions as the price for political quiescence. In Figure 6.2 we therefore exclude the non-capitalist rentrecipients completely, not because they were completely absent but because they did not play a decisive role in the pattern of rent allocation in South Korea at this time. 


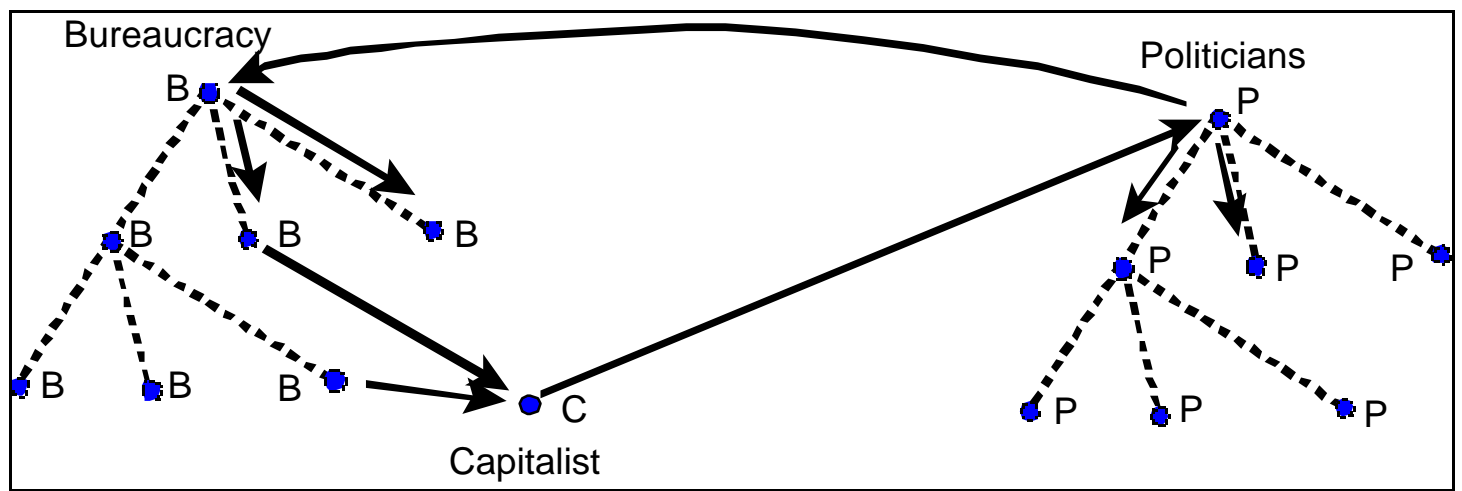

Figure 6.2 Rent flows in South Korea: 1960s and 1970s

This outline is consistent with the accounts that are by now well-known of the flows associated with industrial policy in South Korea (see in particular Amsden 1989; Kim \& Ma 1997). The most important feature of the rent flows during this period was the transfer of subsidies from the state's bureaucratic apparatus (B) to emerging capitalists (C). Second, we now know that there were also in exchange substantial kickbacks from these favoured industrial groups $(\mathrm{C})$ to the political leadership $(\mathrm{P})$ as rents from the growing industrial sector were re-distributed to the political leadership and through them to bureaucrats (B) as well (Kong 1996; Khan 1996a, 1996b). These revelations emerged during the corruption cases that surfaced in the early 1990s, from which we can piece together a story about how bribes were shared by the top politicians and bureaucrats during the 1960s, 1970s and 1980s.

The important difference of South Korean rent flows from the pattern observed in the Indian subcontinent is the absence of competing and decentralized centres of political power, which could demand rent redistribution to themselves. This had important consequences for the efficiency with which rents for learning could be administered by the central leadership of the state. Under those conditions, the inability of rent recipients to mobilize local power in protecting their rents was an important factor allowing developmental states to play a valueenhancing role. The distribution of organizational power in South Korea prevented individuals unrelated to industrial policy from bargaining for rent redistributions during a critical phase of development when the state was creating and allocating rents for learning to accelerate industrialisation (Woo-Cumings 1997).

The absence of a large number of redistributive groups led by a powerful intermediate class in South Korea can in turn be traced to Korea's social history and the nature of the Japanese colonial impact, which prevented these classes from developing or consolidating (Kohli 1994). The Japanese, unlike the British, did not rule through the creation of supporters and administrators within the local population. Instead they relied to a much greater extent on Japanese colonial administrators at all higher levels. This had much to do with Japan's geographical proximity and demographic dominance over its colonies as well as perhaps to differences in colonial ideology. The Japanese colonial state was thus responsible for far-reaching social changes, often carried out with great harshness. This kind of social engineering destroyed the power base of the landed elite. It transferred between a quarter and a third of arable land to Japanese entrepreneurs and corporations (Kohli 1994, pp. 1277-9). At the same time considerable investments took place in industry and agriculture, which created employment opportunities in the productive sector. 
The Japanese colonial goal in its neighbouring colonies was not to extract a few resources and maintain a captive market at the lowest political cost, which was the objective of the British in their far-flung colonies. Instead they aimed to convert Korea into a productive base for Japan and eventually to absorb it into Japan (Kohli 1994, pp. 1272-4). The social development of Korea under Japan meant that landlords and the urban professional and middle classes who caused the greatest political headaches for post-colonial industrializing states either remained very weak because they were never part of the political and administrative coalition which was running the colony. In contrast, the British could only run their vast and far-flung colonies by selectively accommodating groups that had organizational power. To say that South Korea benefited from this social history is not to deny the importance of the leadership role of the state under Park Chung-Hee, nor the importance of the specific institutional arrangements under which rents for learning were administered during the industrial policy phase. At the same time, we know that similar institutional attempts to discipline recipients of subsidies failed in other countries (such as Pakistan in the 1960s) which had inherited a different social organization (see, for instance, Khan 1995, 2000b).

The pattern of South Korean rent flows shown in Figure 6.2 did not remain unchanged over time. Rapid economic development created a large middle class and a civil society, which by the 1980s became increasingly unwilling to accept the high-handed manner in which resources were being allocated by the state. Not surprisingly, by the early 1990s, revelations of corruption increased dramatically even though much of this referred to the efficient rentcreation and rent-sharing of the past. When evidence of contemporary corruption began to emerge there were some indications that the pattern of corruption was also changing by the early 1990s. Evidence of value reducing interlocking between political factions and capitalists begins to emerge. In 1997 the steel company Hanbo went bankrupt amidst allegations that it had continued to receive state support long after its poor economic performance had become well-known. Factions within President Kim Young Sam's party and one of his sons were implicated. In the same year, Kim Young Sam's finance minister seemed to be supporting a takeover of the automobile operations of Kia by Samsung, a strategy that many observers felt was motivated by political rather than economic considerations. The finance minister was closely associated with Samsung, which had also invested in President Kim's home town of Pusan. The episode led to a decline in international confidence in the country and contributed to the financial crisis of 1997.

In commenting on the crisis, Chang et al. (1998) argue that the examples of corruption protecting inefficient rents that were surfacing in South Korea in 1997 were untypical of the broad pattern of corruption in that country. In other words, they subscribe to the view that the gradual abandonment of industrial policy in the 1990s and the shift towards liberalization was an autonomous policy decision taken by the politicians in power. They may be right, but it may also be that by the 1990s real changes were taking place in the distribution of political power in South Korea, which allowed rent-recipients to form political alliances to protect their rents in ways that had not been possible earlier. If this is true, then the shift towards liberalization in South Korea may well have been driven at least partly by the recognition by state leaders that efficient rents could no longer be exclusively protected. The growing 
technical sophistication of South Korean industry was undoubtedly making the regulatory problem for the state more difficult since bureaucrats had less and less competence to judge the performance achieved by recipients of learning rents. If in addition, recipients of inefficient rents were able to protect their rents by forming alliances with politically important factions, industrial policy would have increasingly produced inefficient rent-seeking outcomes reminiscent of he South Asian countries in the 1950s and 1960s. The social changes in South Korea, which may or may not have allowed old-style industrial policy to continue, will be one of the key issues in future South Korean policy debates.

\section{Malaysia}

The South-East Asian countries provide interesting intermediate cases of redistributive rentflows. Unlike South Korea and Taiwan which inherited fairly exceptional social structures as a result of Japanese colonialism (Kohli 1994), the South East Asian countries were closer to the South Asian pattern. Although less powerful and entrenched than in the Indian sub-continent, emergent middle classes in these countries possessed a greater ability to organise political opposition and thereby demand political payoffs compared to their North Asian counterparts. The political and institutional responses in these South East Asian countries show a wide range of variation in terms of the patterns of political side-payments organised to maintain political viability. Malaysia and Thailand provide two interesting contrasts to the South Asian case. In both these countries redistributive rents were much more important than in North Asia but they had far less damaging effects than in the South Asian countries.

While Malaysia inherited a very similar redistributive problem as India, it solved it through a centralized and stable set of redistributions that the losers did not strongly contest. The feature of Malaysia's political economy that allowed a solution to be constructed was paradoxically the ethnic division between capitalists in Malaysia and the rest of the population, which could have spelt disaster. In the 1960s, Malaysia had a capitalist sector based on small-scale trade and production that was dominated by ethnic Chinese capitalists. An emerging Malay middle class was increasingly willing to use its political muscle to organise the Malay majority to get a larger share of the pie for itself. Luckily for Malaysia, the co-incidence of ethnic identities with class ones to some extent helped the organisation of political payoffs in a centralised way.

The orderly solution to the redistributive problem emerged as an unintended consequence of the 1969 riots and the adoption of the New Economic Policy. The political consolidation that took place after the riots of 1969 established UMNO (the United Malays' National Organization) which was the Malay party in the ruling coalition as the dominant political power in the country. Unintentionally, the effect of this was to consolidate potentially competing Malay clientelist groups into a unified structure and at the same time established their political dominance over the capitalists who would have to pay for the redistributive rents. We could therefore characterize Malay clientelism as 'centralized clientelism' compared to the fragmented clientelism afflicting the Indian subcontinent (Khan 1989) or the decentralized but capitalist-led clientelism in Thailand discussed below (see also Doner \& Ramsay 2000; Rock 2000; Khan 2000a; Sidel 1996). 


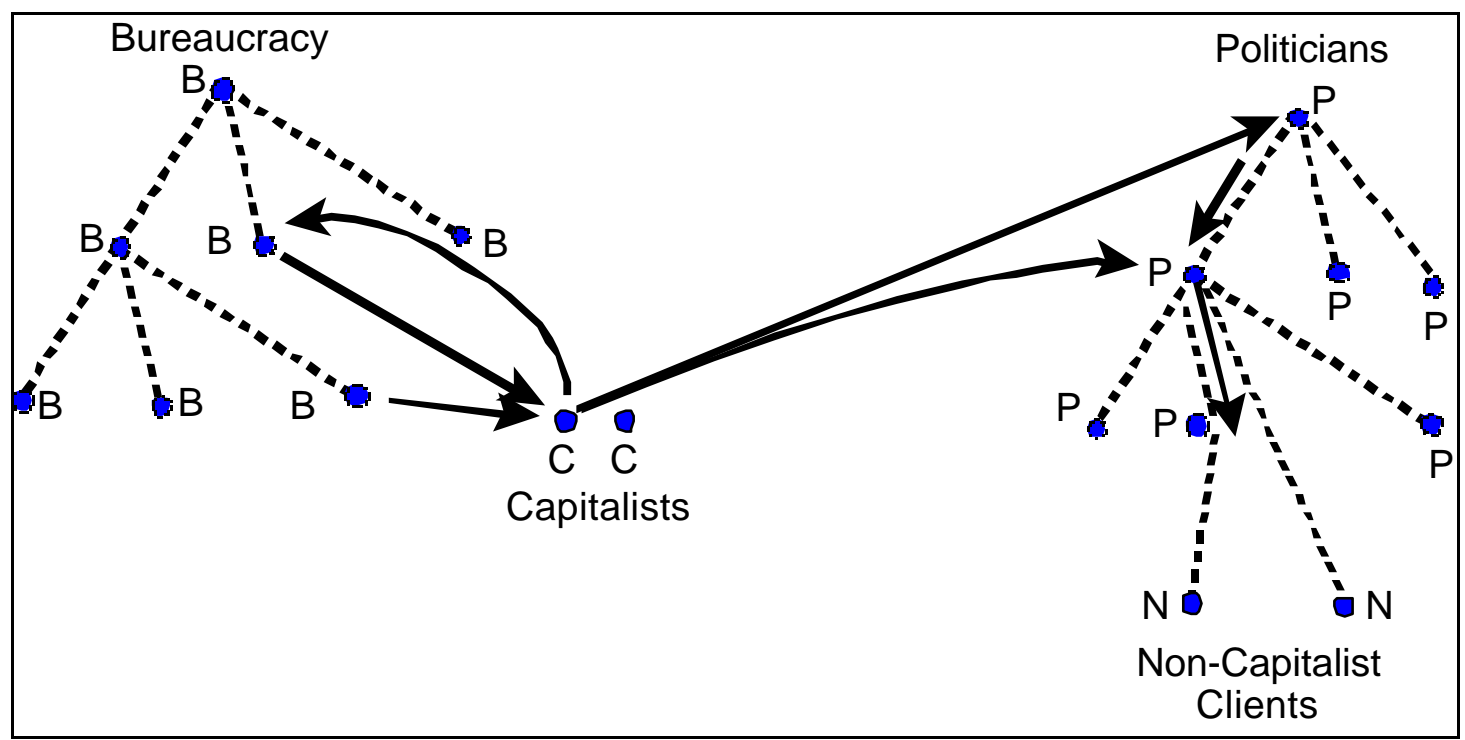

Figure 6.3 Rent flows in Malaysia: 1970s and 1980s

The main features of the rent flows in post-1969 Malaysia are shown in Figure 6.3. The most important transfers are shown in the arrow from the mainly Chinese capitalists $(C)$ to the political leadership of the Malay party $\operatorname{UMNO}(\mathrm{P})$ which dominated the political system. These transfers included both taxes and illegal extractions. The rents extracted were then centrally distributed through the political apparatus to the non-capitalist clients $(\mathrm{N})$ of UMNO shown by the arrows cascading down the political apparatus to non-capitalist clients. In return domestic capitalists received protection and increasingly, assistance for moving into high technology industries through the provision of some subsidies but primarily through state-assisted negotiation of backward linkages with multinationals operating in Malaysia. These rent flows are shown by the arrows from B to C. These subsidies to Malaysia's capitalists were typically not large rents for learning (as in South Korea) but they were nevertheless of economic significance.

The distinctiveness of this system compared to the South Asian system was that rent extraction from the Chinese capitalists was centralised and initially at least, direct links between particular capitalists and political factions in the Indian manner did not exist. This has changed to some extent over time as the Malaysian economy has grown and with it the political power of competing Malay factions within UMNO. But the picture sketched above is reasonably accurate for the late 1960s and early 1970s when Malaysia began its economic takeoff. As decentralized networks developed through the late 1980s and 1990s, we would expect the rent-seeking system would produce fewer value-enhancing rents, as the distribution of political power in Malaysia did not have any obvious proportionality with economic productivity.

The key difference with the South Asian patterns was the centralization and relative stability of the flows in the 1970s and much of the 1980s, which prevented the build-up of dense localised networks of exchanges between capitalists and particular political factions. This can help to explain significant features of the overall pattern of rents and rights created through the corruption and rent-seeking process in Malaysia in its high growth phase. First, the factional alliances that led to inefficient subsidies and sick industries in India were much less in evidence in Malaysia. The structure of rights and subsidies allocated by the state 
could be changed without a huge resistance being offered by large collections of localised intermediate groups. Malay middle-class political elites did not have to extract their redistributive rents by means of decentralized factional alliances with particular capitalists, which we have argued blocked value-enhancing changes in rights in the Indian subcontinent.

Second, the stability of rights and rents that Malaysia achieved as a result allowed it to rely much more heavily on high-technology nvestments by multinationals than either India or South Korea. The centralised political settlement, together with the fact that vast natural resource rents were available for redistribution, allowed domestic redistributive demands to be met by tolerable transfers from the mainly Chinese capitalists. Multinationals could feel secure that internal redistributive conflicts would not spill over to adversely affect them. This confidence proved to have been justified. Multinationals in Malaysia believed that their profits and property rights were secure and this induced them to bring in new technology and progressively use local subcontractors. One could compare this with the successive changes in policy facing multinational power generators like Enron in India in the mid-1990s, even after the onset of liberalization. Not surprisingly, prior to the financial crisis, multinationals in Malaysia were driving export growth and technology acquisition to a greater degree than in most other developing countries (Jomo 1986, pp. 254-6, Jomo and Edwards 1993).

However, there is some evidence that alliances between particular capitalists and competing factions within the Malay political leadership did become more common over the 1980s and 1990s (Jomo \& Gomez 2000). One consequence of this may have been that the pattern of redistributive rents became more unstable and contested, and as a result the state's ability to efficiently reallocate rents and rights decreased. The push for financial liberalization and the development of stock markets, which began to take off in the late 1980s and early 1990s, could not have happened without the political support of powerful factions within the political structure. These differences in factional interests are increasingly evident in the conflict between Prime Minister Mahathir and his deposed deputy, Anwar Ibrahim, who lost power in the aftermath of the financial crisis. Whether these conflicts are purely ideological or whether they reflect a growing factionalisation of the Malay polity as the result of the growth of a more powerful middle class, which cannot be easily accommodated through centralized rent redistribution, remains to be seen.

Paradoxically, the bi-polar ethnic dimension of the redistributive conflict in Malaysia may have helped rather than hindered the construction of a relatively efficient solution, which at least worked effectively for a time. The ethnic isolation of the Chinese capitalist allowed the construction of a fairly explicit and centralised 'tax' system, which taxed capitalists for the benefit of emerging intermediate groups. The language of ethnic deprivation allowed a high proportion of these exactions to be legitimised and therefore organised through centralised and legal party and state structures without secret deals and personalised bargains. This is consistent with the observation that Malaysia was the least corrupt of the group of countries shown in Table 6.1 according to subjective corruption indices. A non-ethnic and purely welfarist argument for transfers would not have been equivalent because it would have required that the bulk of the transfers went to the poorest groups in Malaysia and not necessarily to the leading factions of the intermediate classes, who had the greatest political 
power. Moreover, an argument based on welfarism would probably have been more strongly contested by capitalists since they would not have accepted the redistributive threat to be credible. For these reasons it is difficult to imagine an equivalent ideology in India that could have served to justify a similar centralised transfer from capitalists to the leaders of India's contesting and diverse groups demanding redistribution.

\section{Thailand}

Thailand offers a useful contrast to the other countries in our sample. In contrast to Malaysia, the Chinese capitalists of Thailand were much more ethnically integrated with the Thai middle class. The Malaysian pattern of redistributive rents along ethnic lines did not therefore emerge in Thailand. Thailand was also different from all the countries discussed so far in not having experienced direct colonial occupation and rule. The absence of anticolonial mobilisations explains why the political leadership of its emerging intermediate classes appears to have been weaker compared to the Indian subcontinent or even Malaysia. On the other hand, its intermediate classes were not as atomised as they were in South Korea, which was subjected to Japanese colonialism. Unlike South Korea, where Japanese land reform displaced rural power blocs, Thailand inherited powerful networks of rural politicians who had to be accommodated at a much earlier stage of development. Thus, despite its differences with India, it is quite possible that decentralised networks of patronage would have developed in Thailand to meet the political demands of powerful and largely rural clients. Instead, over the last twenty years Thailand seems to have witnessed a gradual taking over of localised political networks by local capitalists (see, for instance, Phongpaichit \& Baker 1997, pp. 332-354).

The key arrows in Figure 6.4 are the ones showing transfers from capitalists (C) to political factions (P), which allowed many Thai capitalists to take over and run their own political factions to a much greater extent than in other developing countries in Asia. Some of these resources were subsequently used in redistributions to non-capitalist groups who provided political support or votes in elections. Thailand has one of the highest numbers of businessmen in parliament and in cabinet in the region (Sidel 1996; Phongpaichit \& Baker 1997, Tables 10.1 and 10.2). Control over their own factions not only gave Thai capitalists places in parliament. It has also given them the political power to directly bargain for subsidies and the allocation of rights, for instance in the form of franchises and licenses (Doner \& Ramsay 2000). Thus, while Thai capitalists like their counterparts in the other Asian countries have had to make redistributive transfers, much of these transfers were within 'private' political networks that they controlled. 


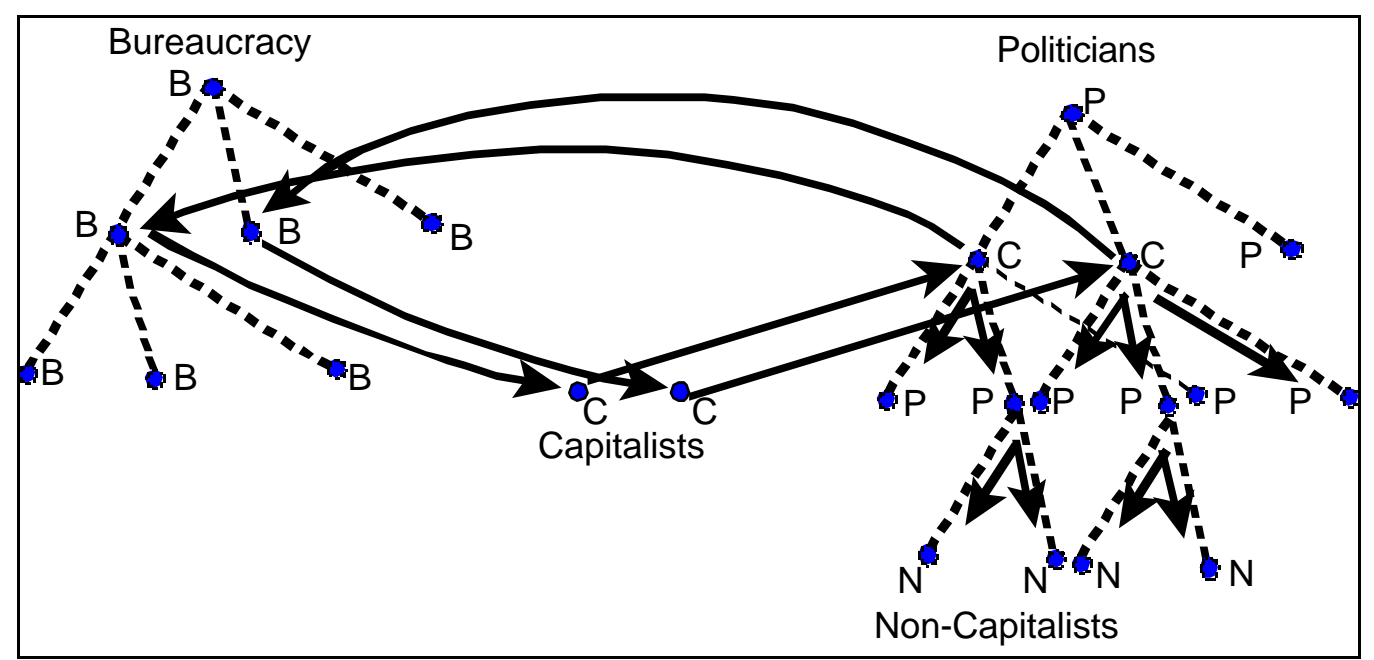

Figure 6.4 Rent flows in Thailand: 1970s and 1980s

The number of capitalists going into the political fray in Thailand has also been large, as a result of a long history of accumulation by small-scale immigrant Chinese traders, many of whom became extremely wealthy over a long period of time. This has ensured vigorous political competition between capitalists for the spoils of power, which has prevented the political system from being monopolised by any particular capitalist faction. Instead there has been vigorous competition for entry into markets through political competition between competing factions in the parliament and the bureaucracy. Though the political costs of this competition have been high in the form of rampant corruption, the long-run economic performance of Thailand has been relatively better than that of its South Asian neighbours because the rights that the capitalist factions were buying through their corruption were on the whole value-enhancing.

How can we explain why this happened? The interesting contrast with the other patterns discussed so far is that unlike Malaysia, the redistributive flows were neither stable nor uncontested in Thailand. This makes Thailand similar to India in this respect. Both countries have decentralized variants of clientelism. However, the difference is that, in Thailand, capitalists were in control of significant chunks of these redistributive coalitions and used their political power achieved through this control to politically compete for rents through the political process. Since the size of the political power they could 'buy' depended on the size of the resources they could muster, there was at least some correlation between the potential productivity of the capitalist and their political power, albeit a very loose one.

Capitalist-led rent-seeking proved to be much more damaging in a period of rapid globalization of financial flows which happened in the early 1990s. When cheap funds became available in virtually limitless supplies from global markets, the crude balance between the political power of rent-seekers to seek rents and their economic productivity was fatally broken. The drive for liberalization was driven by exactly the same processes as the competitive clientelism in the textile industry described by Doner \& Ramsay (2000), but it was no longer even roughly value-enhancing. This is because if capital is available in large enough blocks for speculation, the speculator's bets can become self-fulfilling in the shortrun regardless of any underlying productivity changes as a result of these investments. Financial and property speculators therefore acquired much greater bargaining power and could drive the rent-seeking process even though it was no longer value-enhancing. 
Paradoxically, therefore, globalization may have contributed to the collapse of valueenhancing corruption in Thailand. This means that Thai rent-seeking will have to be much more carefully regulated in the future if its openness to global markets is to be maintained.

\section{Conclusion}

The analysis of corruption is important because it offers an interesting window into the political economy of transition and accumulation processes in developing countries. Drawing the line between 'acceptable' types of accumulation in early capitalism and 'unacceptable' types is never going to be easy. Most processes of primitive accumulation are ugly and politically reprehensible from the standpoint of an advanced capitalist country where the primitive accumulation stage is lost in history. Developing countries face two pragmatic problems. The first is to distinguish between situations where corruption has impoverishing effects from those where corruption allows rapid growth. The economic (as opposed to moral) problem is not corruption per se but the political structures that generate growthretarding corruption. This analysis suggests that anti-corruption strategies which are concerned with the possible effects of corruption on development have to explicitly identify the underlying political problems.

If corruption is politically generated and if the political structure of societies determines the economic effects of the ensuing corruption, in countries where development is blocked the only long run solution may be to provoke a sustained public discussion of such arguments so that new political arrangements can eventually be constructed. The relevant political reforms cannot be generalized and certainly have little to do with the promotion of democracy or of civil society or other such bland objectives (see Khan 1998).

The second and related problem for developmental and progressive policies in developing countries is to think about how the primitive accumulation stage can be made more humanly acceptable for the broader society, which is quite right to regard it as unjust. Here social democratic norms, which may not be immediately achievable, may nevertheless be useful in constructing inclusive political programmes which allow capitalist accumulation to happen while carrying out the maximum possible redistribution to other classes. This is easier said than done, and the experience of Malaysia shows that large-scale redistribution has been successful under very special circumstances. Nevertheless, the challenge even for much more complex redistributive problems faced, say, by India is to construct political movements that can combine acceptable levels of redistribution with capitalist accumulation.

The methods of reform that the conventional approaches have identified - reducing regulation and increasing civil service salaries - are not wrong but are more relevant for addressing residual cases of corruption, which are not driven by systemic forces. We have seen how liberalization has actually increased corruption in India rather than reduced it. The systemic corruption is ultimately driven by political concerns and gets locked in with economic corruption. Addressing it as a fundamentally economic incentive problem is therefore not likely to work. What is worse, since the state's role in creating new property rights and managing transfers to maximize growth while maintaining political stability is not going to disappear, weakening the state by privatisation and liberalisation may make the problem of constructing political solutions to corruption more difficult. We are already 
beginning to see this in countries like Pakistan and Bangladesh. Moreover, game theory approaches to corruption, which appear to address the political and institutional aspects of corruption, actually ignore the critical aspects of political and class power that make the effects of corruption dramatically different across countries in the ways we have briefly discussed.

\section{References}

Ahluwalia, I.J. 1985. Industrial Growth in India. Delhi: Oxford University Press.

Aoki, M., Murdock, K. \& Okuno-Fujiwara, M. 1997. Beyond The East Asian Miracle: Introducing the Market-Enhancing View, in Aoki, M., Kim, H-K and Okuno-Fujiwara, M. The Role of Government in East Asian Economic Development: Comparative Institutional Analysis. Oxford: Clarendon Press.

Amsden, A. 1989. Asia's Next Giant: South Korea and Late Industrialization. Oxford: Oxford University Press.

Bardhan, P. 1984. The Political Economy of Development in India. Oxford: Basil Blackwell.

Bardhan, P. 1997. Corruption and Development: A Review of Issues, Journal of Economic Literature 35: 1320-46.

Chang, H-J. 1994. The Political Economy of Industrial Policy. London: Macmillan.

Chang, H-J, Park, H-J \& Yoo, C.G. 1998. Interpreting the Korean Crisis: Financial Liberalisation, Industrial Policy and Corporate Governance, Cambridge Journal of Economics 22: 735-46.

Doner, R.F. \& Ramsay, A. 2000. Rent-seeking and Economic Development in Thailand, in Khan, M.H. \& Jomo, K.S. eds. Rents, Rent-Seeking and Economic Development. Cambridge: Cambridge University Press.

Harriss-White, B. 1996. Liberalization and Corruption: Resolving the Paradox (A Discussion Based on South Indian Material), IDS Bulletin 27 (2): 31-9.

Jomo, K.S. 1986. A Question of Class: Capital, the State and Uneven Development in Malaya. Singapore: Oxford University Press.

Jomo, K.S. \& Edwards, C. 1993. Malaysian Industrialization in Historical Perspective, in Jomo, K.S. ed. Industrializing Malaysia: Policy, Performance, Prospects. London: Routledge.

Jomo, K.S. \& Gomez, E.T. 2000. The Malaysian Development Dilemma, in Khan, M.H. \& Jomo, K.S. eds. Rents, Rent-Seeking and Economic Development. Cambridge: Cambridge University Press. 
Jones, L. and Sakong, I. 1980. Government, Business and Entrepreneurship in Economic Development: The Korean Case. Cambridge: Harvard University Press.

Khan, M.H. 1989. Clientelism, Corruption and Capitalist Development. $\mathrm{PhD}$ dissertation University of Cambridge.

Khan, M.H. 1995. State Failure in Weak States: A Critique of New Institutionalist Explanations, in J. Hunter, J. Harriss and C. Lewis eds. The New Institutional Economics and Third World Development. London: Routledge.

Khan, M.H. 1996a. A Typology of Corrupt Transactions in Developing Countries, IDS Bulletin 27 (2): 12-21.

Khan, M.H. 1996b. The Efficiency Implications of Corruption, Journal of International Development 8 (5): 683-96.

Khan, M.H. 1998. Civil Society, Patron-Client Networks and the Analysis of Corruption, in OECD/UNDP: Corruption and Integrity Improvement Initiatives in Developing Countries. New York: UNDP, Management Development and Governance Division.

Khan, M.H. 2000a. Rents, Efficiency and Growth, in Khan, M.H. and K.S. Jomo (eds) Rents, Rent-Seeking and Economic Development, Cambridge: Cambridge University Press.

Khan, M.H. 2000b. Rent-seeking as Process, in Khan, M.H. and K.S. Jomo (eds) Rents, Rent-Seeking and Economic Development, Cambridge: Cambridge University Press.

Kim, J.K. 1994. Bureaucratic Corruption: The Case of Korea. Seoul: Cho Myung Press.

Kim, H-K. \& Ma, J. 1997. The Role of Government in Acquiring Technological Capability: The Case of the Petrochemical Industry in East Asia, in Aoki, M., Kim, H-K and OkunoFujiwara, M. The Role of Government in East Asian Economic Development: Comparative Institutional Analysis. Oxford: Clarendon Press.

Kohli, A. 1994. Where Do High Growth Political Economies Come From? The Japanese Lineage of Korea's “Developmental State”, in World Development 22 (9): 1269-93.

Kong, T.Y. 1996. Corruption and its Institutional Foundation, IDS Bulletin 27 (2): 48-55.

Leff, N. 1964. Economic Development through Bureaucratic Corruption, American Behavioral Scientist, reprinted in Ekpo, M.U. (ed.) 1979. Bureaucratic Corruption in Sub-Saharan Africa: Towards a Search for Causes and Consequences. Washington: University of America Press.

Mason, E.S. et. al. 1980. The Economic and Social Modernization of the Republic of Korea. Cambridge: Harvard University Press. 
Mauro, P. 1995. Corruption and Growth, Quarterly Journal of Economics 110 (3): 681712.

Phongpaichit, P. \& Baker, C. 1997. Thailand: Economy and Politics. Oxford: Oxford University Press and Bangkok: Asia Books.

Qian, Y. \& Weingast, B.R. 1997. Institutions, State Activism and Economic Development: A Comparison of State-Owned and Township-Village Enterprise in China, in Aoki, M., Kim, HK and Okuno-Fujiwara, M. The Role of Government in East Asian Economic Development: Comparative Institutional Analysis. Oxford: Clarendon Press.

Rock, M.T. 2000. Thailand's Old Bureaucratic Polity and its New Semi-Democracy, in Khan, M.H. and K.S. Jomo (eds) Rents, Rent-Seeking and Economic Development, Cambridge: Cambridge University Press.

Roy, R. 1996. State Failure in India: Political-Fiscal Implications of the Black Economy, IDS Bulletin 27 (2): 22-30.

Rudolph, L.I. \& Rudolph, S.H. 1987. In Pursuit of Lakshmi: The Political Economy of the Indian State. Chicago: The University of Chicago Press.

Shleifer, A. and Vishny, R. W. 1993. Corruption, Quarterly Journal of Economics, Vol 108 (3): 599-617.

Sidel, J. T. 1996. Siam and its Twin? Democratization and Bossism in Contemporary Thailand and the Philippines, IDS Bulletin 27 (2): 56-63.

Wade, R. 1985. The Market for Public Office: Why the hdian State is not Better at Development, World Development 13 (4): 467-97.

Wade, R. 1989. Politics and Graft: Recruitment, Appointment, and Promotions to Public Office in India, in Ward, P.M. (ed.) Corruption, Development and Inequality: Soft Touch or Hard Graft? London: Routledge.

Wade, R. 1992. The System of Administrative and Political Corruption: Canal Irrigation in South India, Journal of Development Studies 18 (3): 287-328.

Woo-Cumings, M. 1997. The Political Economy of Growth in East Asia: A Perspective on the State, Market and Ideology, in Aoki, M., Kim, HK and Okuno-Fujiwara, M. The Role of Government in East Asian Economic Development: Comparative Institutional Analysis. Oxford: Clarendon Press.

World Bank 1994. World Development Report 1994. Oxford: Oxford University Press.

World Bank 1997. World Development Report 1997. Oxford: Oxford University Press. 